\title{
REVIEW
}

\section{Carol Rittner and David Smith, eds. No Going Back: Letters to Pope Benedict XVI on the Holocaust, Jewish-Christian Relations and Israel}

(London: Quill Press, 2009), paperback, xii + 180 pp.

Reviewed by Harold Kasimow, Grinnell College

This excellent book, published just before Pope Benedict XVI made his 2009 trip to the Holy Land, consists of thirty-eight letters written to the Pope in response to the following question raised by the editors, Carol Rittner and Stephen D. Smith: "If you had five minutes with Pope Benedict XVI, what would you say to him?" (p. x). Each contributor was also asked to include several questions for discussion and to recommend his or her favorite books on interfaith relations. Among the contributors are distinguished Jewish and Christian scholars, some of whom have devoted decades to healing the nearly two-thousand-year rift between Jews and Christians.

Although the Pope may never read this volume, I see it as a very helpful book that reveals how some Jews and Christians view Benedict's papacy. In spite of the fact that Benedict worked closely with John Paul II and from the beginning of his pontificate stressed that, with regard to Judaism, he would continue on the path of his predecessor, many of these Jewish and Christian writers are not convinced. Many argue quite strongly that there has been a serious deterioration in Jewish-Christian relations. The following are some of the key reasons that contributors give for that deterioration.

Many find the Pope's Holocaust-related actions and statements problematic. For example, some criticize the lifting of the excommunication of the bishops from the Society of St. Pius X, most notably Bishop Richard Williamson, who has publicly denied the Holocaust. The Christian writers seem to be more critical of Benedict's views of the Holocaust than the Jewish writers, claiming that the Pope's statements on the Holocaust are not strong enough. John Roth, one of the most prominent Protestant scholars on the Holocaust, writes: "Christianity alone did not cause the Holocaust, but it was a necessary condition for it" (p. 143). This strong connection between the Holocaust and Christianity is not the view of Benedict. The Pope does not link the Holocaust with traditional Christian anti-Semitism, but sees it as a neo-pagan phenomenon.

Another central concern of many contributors is Benedict's 2008 revision of the 1970 Good Friday Prayer for the Jews. The 1970 version includes the hope that Jews "grow in the love of his [God's] name and in faithfulness to his covenant." Without eliminating the 1970 prayer, Benedict has approved a new, optional prayer (similar to the pre-1970 prayer) that reads: "Let us pray also for the Jews: That our Lord and God may enlighten their hearts, that they may acknowledge Jesus Christ as the savior of all men" (p. 83, n. 2). Sister Audrey Doetzel argues that the revised Good Friday prayer, with its hope for the conversion of the Jews, conflicts with his previous writings (p. 82). 
Perhaps the most controversial issue is the canonization of Pope Pius XII. John Roth tells the Pope to "take a courageous step: State publicly that Pope Pius XII is unworthy of sainthood" (p. 146). He also recommends that the Pope issue an encyclical on the Church and the Holocaust clearly stating that "the Church...failed during the Holocaust" (p. 145). Roth also asks the Pope to embrace religious pluralism, and to say that "Judaism provides a fully valid and truthful path to God, one that does not require Christian mediation or conversion in any way whatsoever" (p. 147). It is one thing for committed Catholics to ask the Pope to slow down the sainthood procedure for Pope Pius XII and quite another for a Protestant academic such as Roth to tell the Pope to stop the process "forever" (p. 146). From my perspective, it is also not helpful for a Protestant academic to tell the Pope that he should give up the idea that members of other faiths are ultimately saved by the grace of Christ.

(Since this book appeared, the church has clarified its positions on some of these issues. Shortly after the excommunication was lifted, the Vatican stated that it was not aware of the views of Bishop Williamson and has made it clear that he must "absolutely and unequivocally distance himself from his remarks" before he can be admitted to episcopal functions in the Church. With regard to the Good Friday prayer, the Pope, in a conversation with the chief rabbis of Israel, stated that the Catholic Church will not seek to convert the Jews. The Pope's trip to Jordan, Israel, and the Palestinian Territories in 2009 did not resolve these difficult issues, which will have to be worked out by Jews and Christians who are involved in Christian-Jewish relations.)

In my judgment, Benedict feels a special relationship to Jews and Judaism, but his primary concern is the Catholic Church, which perhaps causes a major misunderstanding between the Church and the Jewish people. Pope Benedict played a key role in all the controversial issues discussed above. Yet we must understand that his aim was not to antagonize the Jews but to unite the Catholic Church. Unlike some of the book's contributors, I believe that Pope Benedict is as interested in furthering Jewish-Catholic relations as was Pope John Paul II. The current tensions between the Church and the Jewish people arise from Benedict's desire to emphasize not only the similarities but also the differences between the traditions. His view is that in dialogue we must remain faithful to our own traditions. The formidable challenge is to discuss our differences honestly and openly and to respect and honor each other in spite of them. I cannot perceive a significant difference between his and John Paul II's desire for reconciliation with Jews.

I was disappointed, as were the editors, that they found only one Muslim to write a letter for this book. It is even more disappointing that the Muslim contributor advises the Pope to tell the Israelis that they should "dismantle" the state of Israel (p. 36). This request is unfortunate, especially when religious leaders have emerged as powerful voices for peace or war. Nevertheless, this book can serve as an ideal source for courses in Jewish-Christian relations. 